\title{
Biochar-immobilized Sphingomonas sp. and Acinetobacter sp. isolates to enhance nutrient removal: potential application in crab aquaculture
}

\author{
Yalu Shao ${ }^{1,2}$, Hua Zhong ${ }^{1,2, *}$, Xinyu Mao $^{3}$, Hongwei Zhang ${ }^{1,2}$ \\ ${ }^{1}$ School of Water Resources and Hydropower Engineering, Wuhan University, Wuhan 430072, PR China \\ ${ }^{2}$ State Key Laboratory of Water Resources and Hydropower Engineering Science, Wuhan University, Wuhan 430072, PR China \\ ${ }^{3}$ College of Agricultural Engineering, Hohai University, Nanjing 210098, PR China
}

\begin{abstract}
The frequency of water exchange and reducing the risk of eutrophication to surrounding water bodies have always been water-quality control issues in recirculating aquaculture systems. In this study, maize straw biochar prepared through pyrolysis showed great potential for both bacterial immobilization and pollutant adsorption. Heterotrophic bacterial strains of Sphingomonas sp. PDD-57b-25 and Acinetobacter towneri were isolated in situ from wastewater for pollutant remediation through a $16 \mathrm{~S}$ rDNA-based method, which has been rarely reported to date. The selected strains had higher ammonia nitrogen $\left(\mathrm{NH}_{4}{ }^{+}-\mathrm{N}, 63 \%\right)$, nitrite nitrogen $\left(\mathrm{NO}_{2}^{-}-\mathrm{N}_{\text {, }}\right.$ $38 \%$ ), nitrate nitrogen $\left(\mathrm{NO}_{3}{ }^{-}-\mathrm{N}, 25 \%\right)$ and total phosphorus (TP, 35\%) assimilation capacities than those of other widely applied bacteria under similar medium conditions. In addition, more $\mathrm{NH}_{4}{ }^{+}-\mathrm{N}$ $(+16 \%), \mathrm{NO}_{2}{ }^{-}-\mathrm{N}(+14 \%), \mathrm{NO}_{3}{ }^{-}-\mathrm{N}(+17 \%)$ and $\mathrm{TP}(+19 \%)$ was removed by biochar-immobilized isolated strains than dissociated strains, suggesting their use may provide a means of improving water-quality control in recirculating aquaculture. With specific additions $\left(4 \mathrm{~g} \mathrm{l}^{-1}\right)$ of biocharimmobilized Sphingomonas sp. PDD-57b-25 and A. towneri, the dissolved inorganic nitrogen (approximately $0.45 \mathrm{mg} \mathrm{l}^{-1}$ ) and TP (approximately $0.09 \mathrm{mg} \mathrm{l}^{-1}$ ) levels were maintained below the clean water threshold for recirculating aquaculture of crab Eriocheir sinensis. Furthermore, the added strains exhibited high bio-safety and were capable of improving the yield and quality of crabs. Results indicate the potential applicability of biochar-immobilized Sphingomonas sp. PDD57b-25 and A. towneri in agricultural sewage treatments. Further, the experimental methodology developed here may be used for the exploration of new strains for practical aquaculture.
\end{abstract}

KEY WORDS: Sphingomonas · Acinetobacter · Eriocheir sinensis aquaculture · Inorganic nitrogen • Phosphorus

\section{INTRODUCTION}

Crab Eriocheir sinensis aquaculture is one of the most important agricultural industries in Jiangsu Province, China, and plays a vital role in the promotion of local economies and human living standards. According to a survey in 2018, the total area of crab aquaculture in China was approximately 2 million ha, crab yield exceeded 40 million $\mathrm{t}$, and annual produc-

*Corresponding author: zhonghua21cn@126.com tion reached US\$ 30 billion (J. Yu et al. 2019). Due to the rapid expansion of intensive crab aquaculture, the excessive nutrients in aquaculture water have resulted in significant environmental pollution, which has increased the remediation input costs. With increasing awareness of environmental protection and sustainable development, water-quality control has become a necessary step in aquaculture to decrease agricultural nonpoint source pollution (Gelfand et al. 2003).

() The authors 2020. Open Access under Creative Commons by Attribution Licence. Use, distribution and reproduction are unrestricted. Authors and original publication must be credited. 
Levels of dissolved inorganic nitrogen (DIN) (ammonium nitrogen $\left[\mathrm{NH}_{4}{ }^{+}-\mathrm{N}\right]$, nitrite nitrogen $\left[\mathrm{NO}_{2}^{-}-\mathrm{N}\right]$ and nitrate nitrogen $\left.\left[\mathrm{NO}_{3}{ }^{-}-\mathrm{N}\right]\right)$ and total phosphorus (TP) are 2 important parameters in crab aquaculture, as these nutrients can be toxic at high concentrations and hazardous to crab health (N. Yu et al. 2019). Generally, the abovementioned nutrients are derived from the metabolic waste of aquatic animals and microbial decomposition of the remaining fish bait. Lowering their concentrations to within environmentally friendly ranges is a key issue in the successful implementation of crab aquaculture. Water replacement is the most widely applied approach to maintain DIN and TP at desirable levels in conventional crab cultivation (Qin et al. 2019). However, with this strategy, discharged nutrients can result in eutrophication of surrounding water bodies. Moreover, any included pathogens may be dispersed, which could be hazardous to plants and animals.

Recently, the recirculating aquaculture system (RAS), which uses microbes and water-processing equipment, has become a popular approach to waterquality maintenance. Nevertheless, the comparatively low recirculating efficiency and high cost restrict its large-scale application, and improving RAS performance in terms of denitrification and phosphorus removal is key to overcoming these bottlenecks. Currently, removal of DIN is typically achieved through nitrification and denitrification processes (Liu et al. 2016, S. Li et al. 2019). These processes involve several biochemical reactions and require alternating between anaerobic and aerobic conditions to ensure suitable performance. In this way, nitrifying and denitrifying bacterial activity imbalances can occur, which may result in the accumulation of $\mathrm{NO}_{2}^{-}$and $\mathrm{NO}_{3}{ }^{-}$ (Liang et al. 2014). In addition, RAS nitrogen removal is conducted with autophytic bacteria in a process that requires extra equipment, such as biofilters or biocarriers, to enhance bacterial propagation and function; however, notable enhancement is still lacking (Zhu et al. 2019). Unlike nitrogen, the phosphorus in aquaculture sewage is generally removed through chemical precipitation by using agents such as iron or aluminum salts (Wu et al. 2019). However, such chemical remediation approaches have the potential to threaten aquatic animal health and increase secondary pollution. Even though the biological phosphorus removal method using algae has been developed to overcome the aforementioned shortcomings, studies on the mechanisms of phosphorus assimilation and optimal conditions for algal growth are rare and therefore this technique still lacks experimental support (Filipe et al. 2001, Acevedo et al. 2015, Zhou et al. 2016).
Because of these bottlenecks, wastewater-borne bacteria have received much attention in RAS waterquality control. These organisms are heterotrophic bacteria that possess nitrogen and phosphorus assimilation capabilities and can convert nutrients into cellular biomass. Due to their rapid adaptability and preferable ammonium removal and phosphorus accumulation potential in aquatic environments, these bacteria may be suitable alternatives to other widelyused bacteria for water remediation (Sun et al. 2015). It is critical to examine strains of wastewater-borne bacteria more closely and to improve their nutrient removal efficiency; only a few suitable strains have been isolated and identified in aquaculture sewage thus far. Moreover, most of these strains are efficient at ammonium removal and phosphorus accumulation under certain medium conditions, but their application in high-content natural aquaculture wastewaters has been rarely reported (Zhu et al. 2018). To enhance the performance of selected ammonia nitrogen removal strains (ANRSs) and phosphate removal strains (PRSs), biochar possessing a large specific surface area (SSA) and complex pore structure could be used in conjunction with bacteria. Due to attachment effects, biochar can serve as a habitat to simultaneously promote bacterial propagation and reduce nitrogen and polyphosphate $\left(\mathrm{PO}_{4}{ }^{3-}, \mathrm{HPO}_{4}{ }^{2-}, \mathrm{H}_{2} \mathrm{PO}_{4}{ }^{-}\right)$ concentrations in chicken farm effluents (AgyarkoMintah et al. 2017). However, research on the enhanced performance of biochar-based probiotics on nutrient removal in RAS is still lacking.

The objectives of this study were as follows: (1) to characterize the physico-chemical properties of prepared biochar and assess its bacterial immobilization and nutrient adsorption potential, (2) to isolate and identify wastewater-borne strains of bacteria that possess optimal nitrogen and phosphorus assimilation capacities, (3) to evaluate the enhancement of biochar-immobilized bacteria on nitrogen and phosphorus removal and (4) to elucidate the waterquality control and bio-safety effects of biocharimmobilized bacteria on recirculating Eriocheir sinensis aquaculture.

\section{MATERIALS AND METHODS}

\subsection{Experimental design}

The experiments were implemented in 3 steps. First, maize straw biochar was prepared through pyrolysis for bacterial adsorption, and optimal ANRSs and PRSs were selected and identified through 
a 16S rDNA method (Fergola et al. 2007, Fitzgerald et al. 2015). Second, the performance of the biocharimmobilized isolated strains on sewage remediation was measured in laboratory-scale experiments. Relative nutrient-removal enhancement was estimated by comparing the efficiencies of the ANRS and PRS among different treatments. Third, the biocharimmobilized isolated strains were applied in practical crab aquaculture. Dynamic variations of nutrients were monitored, and the survival rate of crabs was measured to evaluate biosafety and application potential of the ANRS and PRS. All treatments and relevant analyses were conducted in triplicate.

\subsection{Sewage collection and analysis}

The sewage samples were collected from Eriocheir sinensis aquaculture ponds in Guchen Lake $\left(31^{\circ} 14^{\prime} \mathrm{N}\right.$, $\left.118^{\circ} 53^{\prime} \mathrm{E}\right)$, Nanjing city, Jiangsu Province, China. The samples were stored in cool conditions $\left(4^{\circ} \mathrm{C}\right)$ before use; the water-quality parameters and determination methods of the collected aquaculture sewage are summarized in Table 1. All analyses were conducted in triplicate. The concentrations of heavy metal(loid)s were below the safety threshold of the Chinese Water Quality Standard for Fisheries (serial number GB 11607-89). The $\mathrm{NH}_{4}{ }^{+}-\mathrm{N}, \mathrm{NO}_{2}{ }^{-}-\mathrm{N}, \mathrm{NO}_{3}{ }^{-}-\mathrm{N}$, total nitrogen (TN) and TP concentrations were 8.6, $1.4,0.7,12.7$ and $2.5 \mathrm{mg} \mathrm{l}^{-1}$, respectively, thereby reaching a severe eutrophication level according to the classification criteria of the Environmental Quality Standard for Surface Water (GB 3838-2002).

\subsection{Preparation of the biochar-immobilized bacteria}

\subsubsection{Biochar production and characterization}

Maize straw of the variety Suyu No. 9 (Nanjing Lianghua Ecological Agriculture Technology Development Co.) was selected to produce biochar for the immobilization of bacteria. Maize straw (20 g) was first weighed and broken into small pieces $(5 \mathrm{~mm}$ length). The straw was then placed in a $1000 \mathrm{ml}$ porcelain crucible and pyrolysed in a muffle furnace at $400^{\circ} \mathrm{C}$ for $2 \mathrm{~h}$. The pyrolysis was maintained in anoxic conditions at a heating rate of $10^{\circ} \mathrm{C} \mathrm{min}^{-1}$. Subsequently, the prepared maize straw biochar was washed with deionized water and stored in a plastic bag for characterization after grinding (particle diameter: <0.5 mm).

The measured physico-chemical properties of the biochar are summarized in Table 2. The carbon yield ( $)$ was calculated through the following equation:

$$
\eta=\frac{M_{\text {Biochar }}}{M_{\text {Biomass }}} \times 100 \%
$$

where $M_{\text {Biochar }}(g)$ represents the mass of biochar and $M_{\text {Biomass }}$ represents the mass of maize straw before pyrolysis.

The measurement of ash content was compared to the national standard (GB/T 12496); $1 \mathrm{~g}$ of maize straw was put into a crucible and pyrolysed in a muffle furnace at $800^{\circ} \mathrm{C}$ to a constant weight. The ash content (\%) was determined by:

$$
\text { Ash content }=\frac{M_{2}-M_{1}}{M} \times 100 \%
$$

where $M$ is the mass of maize straw before ashing, $M_{1}$ is the mass of the crucible after drying and $M_{2}$ is the mass of the maize straw biochar and crucible after ashing. 
Table 2. Mean $( \pm \mathrm{SD})$ physico-chemical properties of the maize straw biochar prepared through a $2 \mathrm{~h}$ pyrolysis at $400^{\circ} \mathrm{C}$

\begin{tabular}{|lcc|}
\hline Parameter & Unit & Value \\
\hline Carbon yield & $\%$ & $47.6 \pm 2.7$ \\
Ash content & $\%$ & $38.2 \pm 3.5$ \\
$\mathrm{pH}$ & & $8.6 \pm 0.4$ \\
Electrical conductivity & $\mu \mathrm{S} \mathrm{cm}^{-1}$ & $2032 \pm 236$ \\
Dissolved organic carbon & $\mathrm{mg} \mathrm{g}^{-1}$ & $11.2 \pm 1.3$ \\
H/C & & $0.83 \pm 0.05$ \\
O/C & & $0.46 \pm 0.03$ \\
\hline
\end{tabular}

The $\mathrm{pH}$ and electrical conductivity of biochar were measured using a $\mathrm{pH}$ meter (GB/T 12496) and conductivity meter (GB/T 24525), respectively. Dissolved organic carbon was determined using a total organic carbon analyzer (GB/T 3257). The mass ratios of biochar carbon and hydrogen were measured with an elemental analyzer (GB/T 15460); the mass ratio of oxygen was achieved by deducting the ash quality based on the mass balance. The surface structure of the biochar was observed via scanning electron microscopy (SEM). Moreover, the SSA, pore volume and pore diameter of the biochar were measured with a SSA and aperture analyzer (GB/T 19587): first, $\mathrm{N}_{2}$ adsorption-desorption isotherm tests were carried out $\left(-196.15^{\circ} \mathrm{C}\right)$ with a $2 \mathrm{~h}$ pre-degassing process of biochar at $200^{\circ} \mathrm{C}$; then SSA was calculated using the Brunauer-Emmett-Teller (BET) method, and the total pore volume was determined under specific relative pressure $\left(P / P_{0}=0.95\right)$; subsequently, the $t$-plot method was applied to determine the micropore volume and the Barrett-Joyner-Halenda (BJH) method was utilized to calculate the pore size distribution.

\subsubsection{Bacterial isolation and screening}

A synthetic medium consisting of NaAc $\left(3 \mathrm{~g} \mathrm{l}^{-1}\right)$, $\mathrm{Na}_{2} \mathrm{HPO}_{4}\left(30 \mathrm{mg} \mathrm{l}^{-1}\right), \mathrm{NH}_{4} \mathrm{Cl}\left(60 \mathrm{mg} \mathrm{l}^{-1}\right), \mathrm{MgSO}_{4}$ $\left(130 \mathrm{mg} \mathrm{l}^{-1}\right), \mathrm{K}_{2} \mathrm{SO}_{4}\left(25 \mathrm{mg} \mathrm{l}^{-1}\right)$ and $\mathrm{CaCl}_{2} \cdot 2 \mathrm{H}_{2} \mathrm{O}$ (18 $\mathrm{mg} \mathrm{l}^{-1}$ ) was prepared for bacterial isolation. Additional $\left(\mathrm{NH}_{4}\right)_{2} \mathrm{SO}_{4}\left(200 \mathrm{mg} \mathrm{l} \mathrm{l}^{-1}\right)$ and $\mathrm{K}_{2} \mathrm{HPO}_{4}$ (100 $\mathrm{mg} \mathrm{l}^{-1}$ ) were added individually to the base synthetic medium for ANRS and PRS screening, respectively. Moreover, beef extract medium, which contained beef extract (5 $\left.\mathrm{g} \mathrm{l}^{-1}\right)$, peptone $\left(10 \mathrm{~g} \mathrm{l}^{-1}\right)$, $\mathrm{NaCl}\left(15 \mathrm{~g} \mathrm{l}^{-1}\right)$ and agar $\left(20 \mathrm{~g} \mathrm{l}^{-1}\right)$, was applied for further enrichment of the selected bacteria. The $\mathrm{pH}$ levels of the abovementioned mediums were adjusted to 7.0 before use.
Aquaculture sewage was added to the synthetic medium at a volume ratio of 9:1 (total volume: $250 \mathrm{ml}$ ) for bacterial incubation at $25^{\circ} \mathrm{C}$ in a shaker. After $48 \mathrm{~h}$, an aliquot of bacterial solution was extracted on Luria-Bertani agar plates and incubated overnight at $25^{\circ} \mathrm{C}$. Then, based on the colony morphologies, potential target bacterial colonies were selected and transferred to the beef extract medium for enrichment (de-Bashan et al. 2008). Thereafter, the enriched bacteria were streaked twice on the synthetic medium for purification, and specific strains (10 each) of the potential $\mathrm{NH}_{4}{ }^{+}-\mathrm{N}$ and TP removal bacteria were obtained. The selected strains were cultured overnight, and the bacterial cell densities were adjusted to $1 \times 10^{8} \mathrm{cfu} \mathrm{ml}^{-1}$. Subsequently, the selected strains (1 $\mathrm{ml}$ each) were incubated in the synthetic medium (1 l) for $48 \mathrm{~h}$ at $25^{\circ} \mathrm{C}$. The initial and final $\mathrm{NH}_{4}{ }^{+}-\mathrm{N}$ and TP contents in the medium were measured to determine the most suitable strains for nutrient removal. The selected strains were stored $\left(-20^{\circ} \mathrm{C}\right)$ for genomic identification and subsequent experiments.

\subsubsection{Identification of the selected strains}

The bacterial strains that possessed optimal $\mathrm{NH}_{4}{ }^{+}-\mathrm{N}$ and TP removal abilities were identified through a 16S rDNA-based method. The genomic DNA of the strains was extracted using a DNA extraction kit (TaKaRa). The primers $27 f$ (5'-AGR GTT GAT CMT GGC TCA G-3') and 1492r (5'-GYT ACC TTG TTA CGA CTT-3') were further applied for PCR amplification of the 16S rDNA gene sequences (Liu et al. 2014, Chen et al. 2016). The obtained sequences were then compared with known sequences in the GenBank database using BLAST, and the genomic homologies between the isolated and GenBank strains were analyzed.

2.3.4. Adsorption of isolated bacterial strains on the prepared biochar

For bacterial adsorption, $1 \mathrm{~g}$ of prepared biochar was mixed with $10 \mathrm{ml}$ isolated ANRS or PRS (cell density: $1 \times 10^{8} \mathrm{cfu} \mathrm{ml}^{-1}$ ). The mixtures were added into $250 \mathrm{ml}$ conical flasks, and sterile water was added to adjust the total volume to $100 \mathrm{ml}$. Then the mixtures were incubated in a shaker (160 rpm) for $6 \mathrm{~h}$ at $25^{\circ} \mathrm{C}$. Afterwards, the bacterial cell densities in the supernatant liquid were measured using the plate count method. In this way, we further determined the total ANRS and PRS amounts that had been adsorbed 
onto the biochar surface, which were approximately $6.3 \times 10^{7}$ and $4.5 \times 10^{7} \mathrm{cfu} \mathrm{g}^{-1}$, respectively.

\subsection{Biochar-immobilized isolated bacteria for enhanced nutrient removal}

Batch experiments were conducted at laboratoryscale to evaluate the performance and enhancement of nitrogen and phosphorus removal by biocharimmobilized isolated bacteria. In this step, 5 treatments were defined: a control group without the addition of agent (T1); sewage remediated with effective microorganisms (EMs) (T2); sewage remediated with prepared maize straw biochar (T3); sewage remediated with unfixed ANRSs and PRSs (T4); and sewage remediated with biochar-immobilized ANRSs and PRSs (T5). The EMs were purchased from EMROCHINA and are currently among the most widely applied water purification agents in crab aquaculture. To simulate the practical crab aquaculture environment, the $\mathrm{pH}$, light intensity, temperature, air humidity and dissolved oxygen (DO) levels were controlled at approximately $7.0,100 \mu \mathrm{mol} \mathrm{m}{ }^{-2} \mathrm{~s}^{-1}, 25^{\circ} \mathrm{C}, 40 \%$ and $10 \mathrm{mg} \mathrm{l}^{-1}$, respectively. The $\mathrm{NH}_{4}{ }^{+}-\mathrm{N}, \mathrm{NO}_{2}{ }^{-}-\mathrm{N}_{1} \mathrm{NO}_{3}{ }^{-}-\mathrm{N}$ and TP contents were measured every $12 \mathrm{~h}$, and the nutrient removal efficiencies among the different treatments were compared after $120 \mathrm{~h}$.

\subsection{Application potential of biochar-immobilized isolated bacteria in crab aquaculture}

In this step, the RAS, which included a polypropylene aquaculture pond, drum micro-filter, aerator, programmable temperature chamber, ozonateur and sewage pump, was applied to Eriocheir sinensis aquaculture $(\mathrm{n}=3$ ponds per treatment; untreated control vs. biochar-treated). A dosage of the biochar-immobilized isolated bacteria was homogeneously added to the polypropylene pond without water exchange during the aquaculture. Environmental conditions were monitored daily and strictly controlled within the desired range as mentioned in Section 2.4: $\mathrm{pH}$ was measured by the glass electrode method (GB 11901), light intensity was detected with an underwater irradiance meter (GB 7000), temperature and DO levels were monitored by a water-quality analyzer (GB T31962), and air humidity was determined using a capacitive digital hygrometer (GB T18204). In addition, the dynamic variations in DIN $\left(\mathrm{NH}_{4}{ }^{+}-\mathrm{N}_{1} \mathrm{NO}_{2}{ }^{-}-\mathrm{N}\right.$ and $\mathrm{NO}_{3}{ }^{-}-$ $\mathrm{N}$ ) and TP contents were measured every $5 \mathrm{~d}$ during the aquaculture process (90 d) to assess the water re- mediation efficiencies of the biochar-immobilized isolated bacteria in the RAS. The methods and relevant standards for nutrient measurements are summarized in Table 1. At the end of the experiment, random sampling (50 samples) of $E$. sinensis from both sets of polypropylene aquaculture ponds was conducted. Indexes of survival rate, weight, stocking density, biomass, crude protein, crude fat and water content (GB T19957) were determined to evaluate the bio-safety and potential application of the biochar-immobilized isolated bacteria for aquaculture within a RAS.

\subsection{Statistical analysis}

The data were processed and averages calculated in Microsoft Excel. Relevant standard deviations were statistically analyzed in SPSS v.11.5 software for illustrating the degree of dispersion in the data. The calculations and analysis in BET, $t$-plot and BJH methods were conducted in Origin v.8.5. In addition, Duncan's multiple range tests in MATLAB v.7.0 were applied for analysis of nitrogen and phosphorus removal rates with utilization of the biochar-immobilized isolated bacteria $(\mathrm{p}<0.05)$.

\section{RESULTS AND DISCUSSION}

\subsection{Characterization of maize straw biochar}

The SEM results of the maize straw biochar prepared through $2 \mathrm{~h}$ of pyrolysis $\left(400^{\circ} \mathrm{C}\right)$ are presented in Fig. 1. The biochar surface observed under 1000x SEM magnification was rough, with a complex pore structure (Fig. 1a). The surface pores that were irregularly distributed across the cellular structure were much clearer under 2500× magnification (Fig. 1b). Generally, the surface pore volume and diameter of the biochar strongly determine its SSA, which is closely related to its bacterial adsorption potential (Fu et al. 2019). Thus, $\mathrm{N}_{2}$ adsorption-desorption isotherm analysis of the biochar was conducted to reveal its possible surface pore distribution.

As shown in Fig. 2a, under high temperature (77 K), the $\mathrm{N}_{2}$ adsorption-desorption volumes increased from approximately 88 to $163 \mathrm{~cm}^{3} \mathrm{~g}^{-1}$ as an increase of relative pressure $\left(P / P_{0}\right)$. It should be noted that the $\mathrm{N}_{2}$ adsorption-desorption volume increased slowly at low $P / P_{0}(<0.9)$ but increased rapidly when $P / P_{0}>0.9$. This phenomenon indicates that the variations in $\mathrm{N}_{2}$ adsorption-desorption of the prepared biochar in this study were consistent with Type IV isotherms according to 

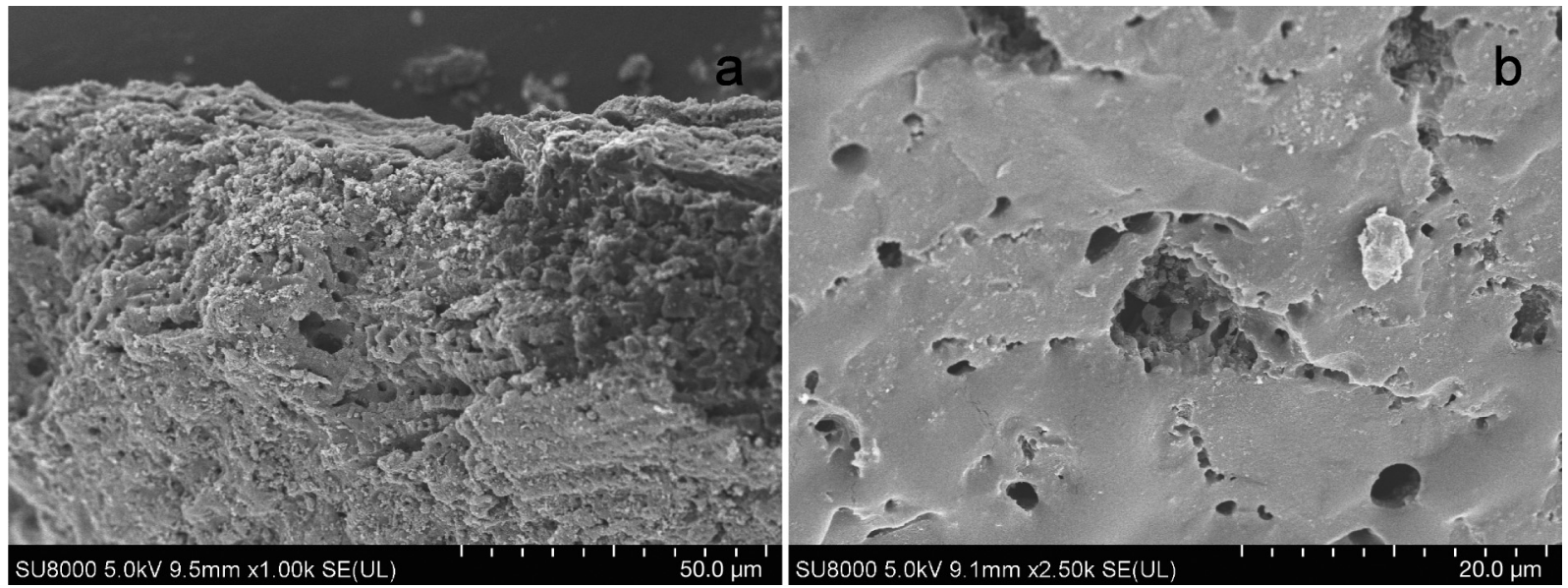

Fig. 1. SEM image of maize straw biochar at (a) $1000 \times$ and (b) $2500 \times$ magnification
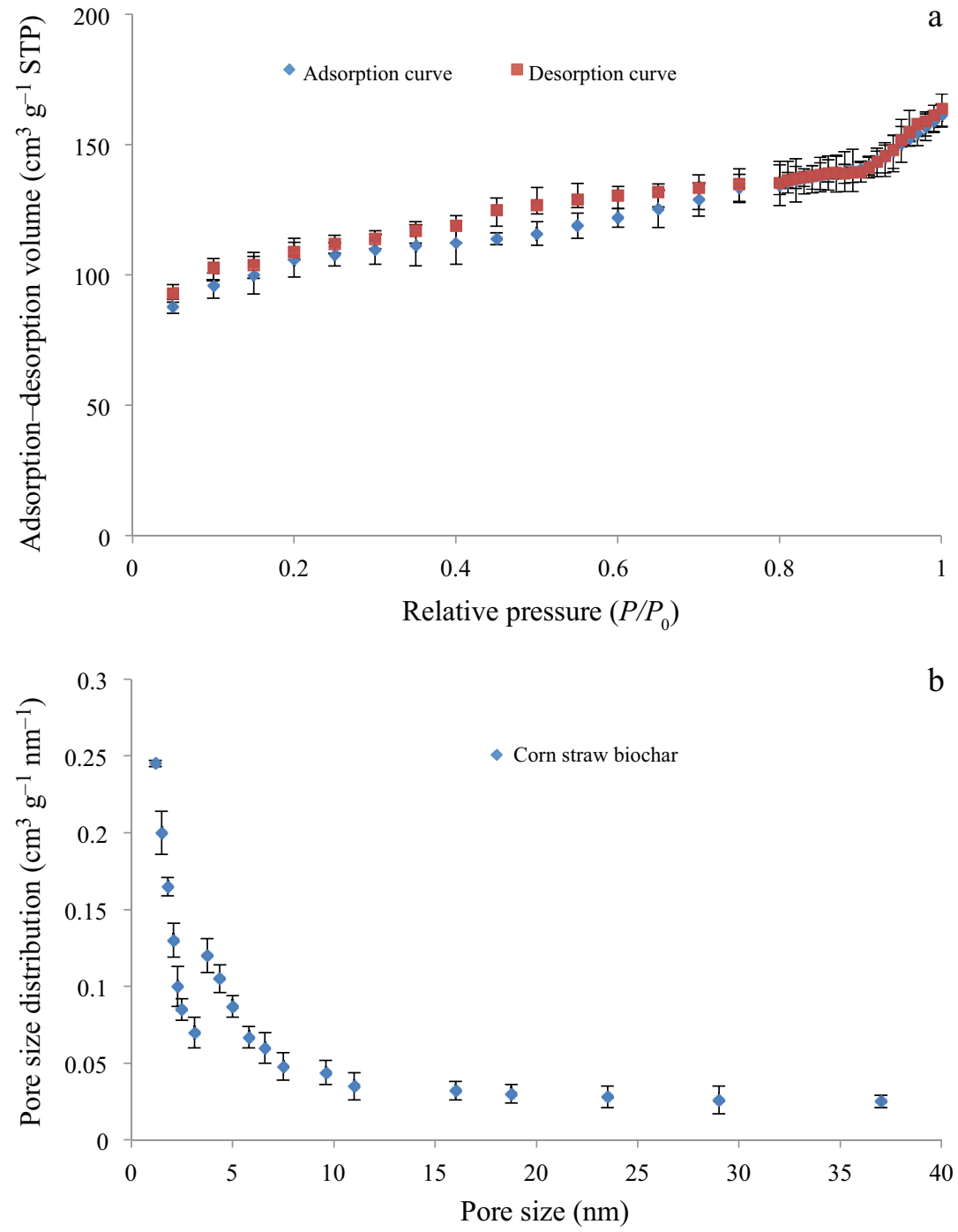

Fig. 2. (a) $\mathrm{N}_{2}$ adsorption-desorption isotherms at standard temperature and pressure (STP) and (b) relative pore size distribution of maize straw biochar. Error bars: SD a the classification criteria reported by the International Union of Pure and Applied Chemistry. No significant difference was observed between the $\mathrm{N}_{2}$ adsorption and desorption curves, which suggests that there were no large pores (pore size: $>50 \mathrm{~nm}$ ) on the surface of the prepared biochar (J. Li et al. 2019, Wang \& Wang 2019). Moreover, a hysteresis loop between the $\mathrm{N}_{2}$ adsorption and desorption curves appeared when $P / P_{0}$ ranged from $0.4-0.65$. This indicates that the pores distributed on the biochar surface mainly consisted of micropores and mesopores $(2 \mathrm{~nm}<$ pore size $<50 \mathrm{~nm}$ ), as depicted in Fig. 2b.

The biochar SSA, total pore volume, micropore volume and average pore size (APS) were further measured using the BET, $t$-plot and BJH methods, respectively (Table 3 ). The high micropore ratio $(79 \%)$ and small APS $(2.84 \mathrm{~nm})$ resulted in a relatively large SSA $\left(376.4 \mathrm{~m}^{2} \mathrm{~g}^{-1}\right)$ of the prepared biochar. This may enable a suitable adsorption capacity for both bacteria and nutrients due to the abundant binding sites on its surface.

\subsection{Nutrient removal potential and identification of selected strains}

The $\mathrm{NH}_{4}{ }^{+}-\mathrm{N}$ and TP removal capacities of the isolated ANRSs and PRSs are presented in Fig. 3. Clearly, dif- 
Table 3. Mean $( \pm \mathrm{SD})$ specific surface area, total pore volume, micropore volume and average pore size of the maize straw biochar

\begin{tabular}{|lcc|}
\hline Indexes & Unit & Value \\
\hline Specific surface area & $\mathrm{m}^{2} \mathrm{~g}^{-1}$ & $376.4 \pm 12.3$ \\
Total pore volume & $\mathrm{cm}^{3} \mathrm{~g}^{-1}$ & $0.212 \pm 0.008$ \\
Micropore volume & $\mathrm{cm}^{3} \mathrm{~g}^{-1}$ & $0.168 \pm 0.007$ \\
Average pore size & $\mathrm{nm}$ & $2.84 \pm 0.04$ \\
\hline
\end{tabular}

ferent strains possessed different $\mathrm{NH}_{4}{ }^{+}-\mathrm{N}$ and TP removal efficiencies. After $48 \mathrm{~h}$ of cultivation, the highest $\mathrm{NH}_{4}{ }^{+}-\mathrm{N}$ and TP removal rates were 58 and $34 \%$, respectively, which were obtained in synthetic media containing the ANRS5 and PRS4 strains. Thus, ANRS5 and PRS4 were good candidates for genetic identification.

The 16S rDNA gene sequences of ANRS5 and PRS4 were further compared with known sequences in the GenBank database with BLAST. The analysis of their genomic homologies are summarized in
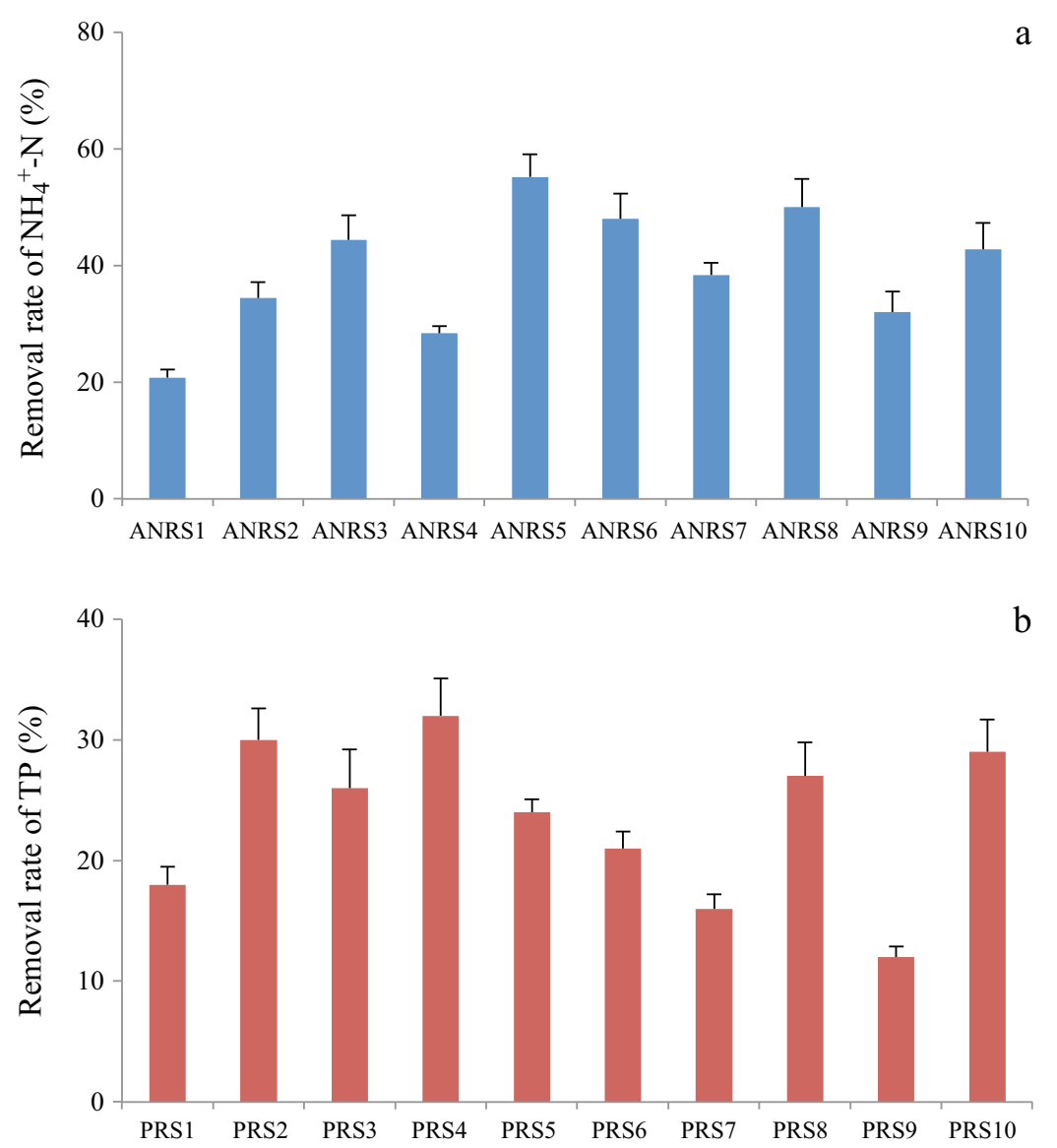

Fig. 3. Comparisons of (a) $\mathrm{NH}_{4}{ }^{+}-\mathrm{N}$ and (b) total phosphorus (TP) removal by different bacterial strains after $48 \mathrm{~h}$ at $25^{\circ} \mathrm{C}$ with initial concentrations of approx. 270 and $130 \mathrm{mg} \mathrm{l}^{-1}$, respectively. Error bars: SD
Table 4. The results indicated that the selected ANRS5 and PRS4 are most likely members of the genera Sphingomonas and Acinetobacter, respectively, due to their high similarity (>98\%). Moreover, through repeated comparisons, ANRS5 and PRS4 were found to have $100 \%$ proximity with Sphingomonas sp. PDD-57b-25 and A. towneri, respectively, of which the known strains in GenBank have accession numbers KR922120 and AF589023. Therefore, we speculated that the wastewater-borne ANRS5 and PRS4 in this study were Sphingomonas sp. PDD-57b-25 and A. towneri, respectively.

\subsection{Enhanced nitrogen and phosphorus removal by biochar-immobilized isolated bacteria}

The $\mathrm{NH}_{4}{ }^{+}-\mathrm{N}, \mathrm{NO}_{2}{ }^{-}-\mathrm{N}, \mathrm{NO}_{3}{ }^{-}-\mathrm{N}$ and TP removal efficiencies in batch experiments are shown in Fig. 4. Since side effects can result in slight intensity variations, the temperature, air conditions and DO levels were well simulated based on previous practical aquaculture data. The results of the batch experiments accurately reflected the pollutant removal performances of the different treatments and revealed possible treatment enhancement using biochar-immobilized ANRS5 and PRS4 (BIAP). BIAP (T5) was added to aquaculture sewage at a ratio of $2 \mathrm{~g}: 1 \mathrm{l}$. The biochar amount and bacterial cell quantity applied in the other treatments (T2-T4) were in accordance with this ratio.

After $120 \mathrm{~h}$, the $\mathrm{NH}_{4}{ }^{+}-\mathrm{N}$ concentration was reduced from 8.6 to $1.8 \mathrm{mg}$ $1^{-1}$, which represents a removal rate of approximately $79 \%$ with biocharimmobilized ANRS5. In addition, decreases in $\mathrm{NO}_{2}{ }^{-}-\mathrm{N}$ and $\mathrm{NO}_{3}{ }^{-} \mathrm{N}$ were observed, with levels decreasing from 1.3 to $0.67 \mathrm{mg} \mathrm{l}^{-1}$ and from 0.67 to $0.37 \mathrm{mg} \mathrm{l}^{-1}$, respectively. The genus Sphingomonas was first reported to have a satisfactory $\mathrm{NH}_{4}{ }^{+}-\mathrm{N}$ degradation ability by Yabuuchi et al. (1990). It was characterized as a beneficial strain for $\mathrm{NH}_{4}{ }^{+}-\mathrm{N}$ oxidation in circulating aquaculture systems or bioreactors. In many cases, $\mathrm{NH}_{4}{ }^{+}-\mathrm{N}$ was reported to be gradually converted into $\mathrm{NO}_{2}{ }^{-} \mathrm{N}$ and subsequently nitrified into $\mathrm{NO}_{3}{ }^{-}-\mathrm{N}$ through 
Table 4. Genomic proximities between the isolated and GenBank strains. ANRS: ammonia nitrogen removal strain; PRS: phosphate removal strain

\begin{tabular}{lc|}
$\begin{array}{l}\text { Strain/rRNA length (bp) } \\
\text { GenBank strain (accession no.) }\end{array}$ & $\begin{array}{c}\text { Proximity } \\
(\%)\end{array}$ \\
\hline ANRS5/1456 & 100 \\
Sphingomonas sp. PDD-57b-25 (KR922120) & 98.63 \\
Sphingomonas sp. aurantiaca (AJ429236) & 99.71 \\
Sphingomonas sp. PDD-60B-30 (KR922201) & 99.28 \\
Sphingomonas sp. NMC17 (GU321356) & 98.85 \\
Sphingomonas sp. PDD-63b-46 (KR922143) & 98.74 \\
Sphingomonas sp. PDD-63b-1 (KR922270) & 98.36 \\
Sphingomonas sp. PDD-57b-28 (KR922123) & 98.18 \\
Sphingomonas sp. Ze13 (KR088450) & \\
PRS4/1447 & 100 \\
Acinetobacter towneri (AF589023) & 99.97 \\
Acinetobacter baylyi (AM410709) & 98.26 \\
Acinetobacter haemolyticus (Z93437) & 98.56 \\
Acinetobacter calcoaceticus (X81661) & 98.36 \\
Acinetobacter lwoffifii (Z93441) & 99.14 \\
Acinetobacter junii (AM410704) & 98.74 \\
Acinetobacter genomic (Z93439) & 99.88 \\
Acinetobacter baumannii (Z93435) & \\
\hline
\end{tabular}

the nitrification processes, which may result in increases of $\mathrm{NO}_{2}^{-}-\mathrm{N}$ and $\mathrm{NO}_{3}{ }^{-}-\mathrm{N}$ in certain periods (Kirimura et al. 1999, Su et al. 2019). However, in the batch experiments with the application of
ANRS5, $\mathrm{NH}_{4}{ }^{+}-\mathrm{N}$ was largely removed within $70 \mathrm{~h}$ without increases of $\mathrm{NO}_{2}{ }^{-}-\mathrm{N}$ and $\mathrm{NO}_{3}{ }^{-}-\mathrm{N}$. These results indicate a higher nitrification efficiency of the selected ANRS5 compared to that of EMs. Furthermore, as heterotrophic bacteria, ANRS5 assimilate $\mathrm{NH}_{4}{ }^{+}-\mathrm{N}, \mathrm{NO}_{2}{ }^{-}-\mathrm{N}$ and $\mathrm{NO}_{3}{ }^{-}-\mathrm{N}$ as cell components, as evidenced by the continuous decreases in $\mathrm{NO}_{2}{ }^{-}-\mathrm{N}$ and $\mathrm{NO}_{3}{ }^{-}-\mathrm{N}$ during the process (Yun et al. 2019).

The immobilized ANRS5 (T5) was able to remove more $\mathrm{NH}_{4}{ }^{+}-\mathrm{N}(16 \%), \mathrm{NO}_{2}{ }^{-}-\mathrm{N}(14 \%)$ and $\mathrm{NO}_{3}{ }^{-}-\mathrm{N}$ $(17 \%)$ compared to the dissociated ANRS5 (T4). These enhancements were attributed to the maize straw biochar since its large SSA and complex pore structure contributed to nitrogen adsorption, which was observed in T3. Furthermore, the attachment sites on the biochar surface provided a habitat for ANRS5, which was beneficial for its growth and prevented bacterial diffusion caused by water flow fluctuations, thus allowing the high nitrogen assimilation activities of ANRS5 (Dalgaard et al. 2011, Rezaei Rashti et al. 2019). The $\mathrm{NH}_{4}{ }^{+}-\mathrm{N}$ removal efficiency in T4 was approximately $28 \%$ higher than that in T2 with application of EMs. This result demonstrated the feasibility of using ANRS5 as an alternative to EMs in controlling water quality. The use of EMs is currently the most widely applied water purification method due to the multiple functions induced by the included pro-
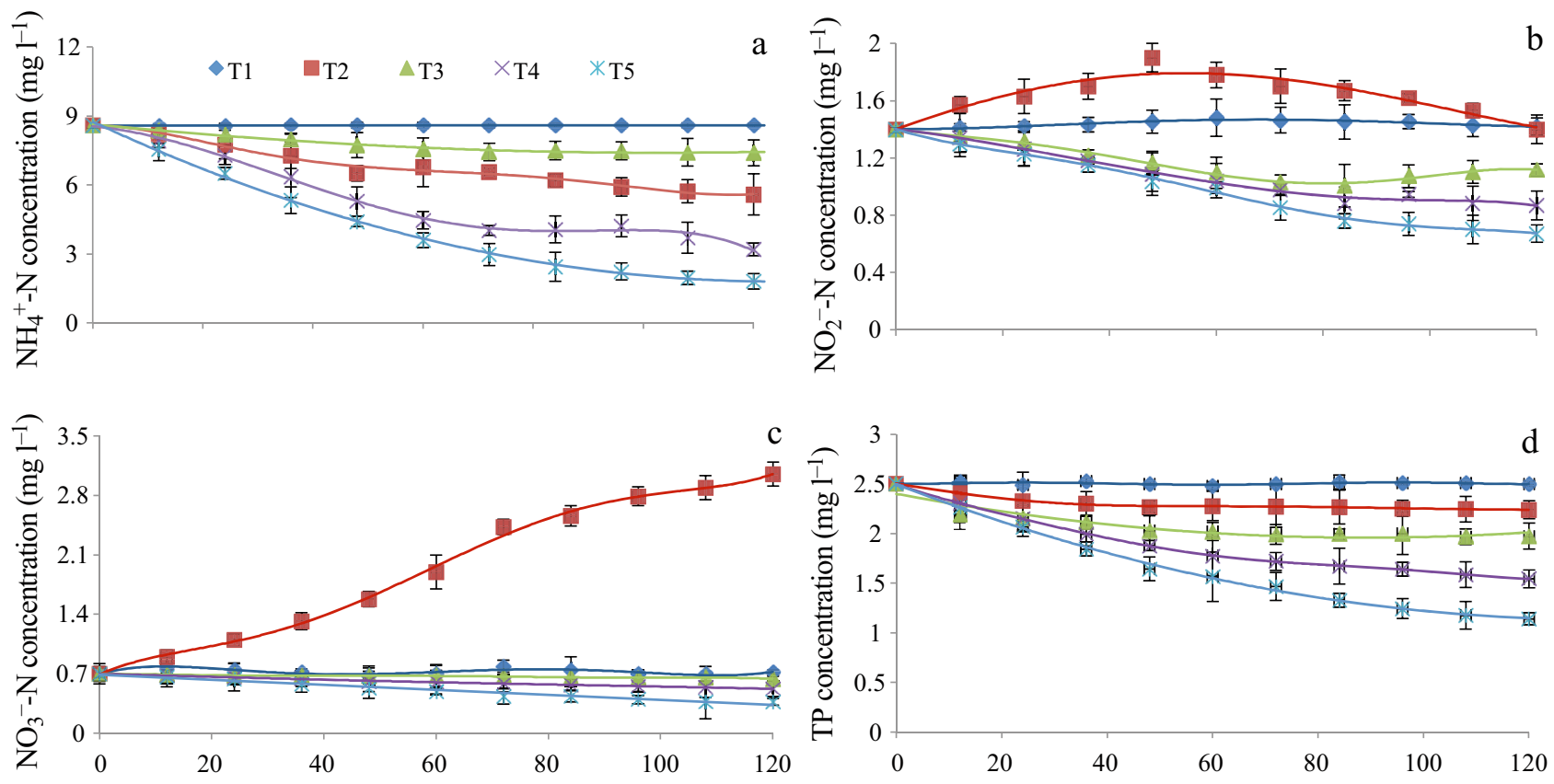

Elapsed time (h)

Fig. 4. Removal of $\mathrm{NH}_{4}{ }^{+}-\mathrm{N}, \mathrm{NO}_{2}{ }^{-}-\mathrm{N}, \mathrm{NO}_{3}{ }^{-}-\mathrm{N}$ and total phosphorus (TP) in aquacultural sewage by control treatment (T1), effective microorganisms (T2), prepared maize straw biochar (T3), unfixed ammonia nitrogen and phosphate removal strains (ANRS and PRS) (T4) and biochar-immobilized ANRS and PRS (T5) in laboratory experiments. Error bars: SD 
biotic bacteria, such as photosynthetic bacteria, bacillus and actinomycetes (Peng et al. 2018). Nevertheless, with the addition of the same cell quantity, the $\mathrm{NH}_{4}{ }^{+}-\mathrm{N}$ removal performance of the EMs was not as good as that of ANRS5. Moreover, the $\mathrm{NO}_{3}{ }^{-}-\mathrm{N}$ content in T2 significantly increased from 0.92 to $3.05 \mathrm{mg} \mathrm{l}^{-1}$, which suggests that EMs might not be able to assimilate $\mathrm{NH}_{4}{ }^{+}-\mathrm{N}$.

Similar enhancements were also obtained in TP removal; the relevant removal rates were ranked as T5 $(54.3 \%)>$ T4 $(35.4 \%)>$ T3 $(13.2 \%)>$ T2 $(10.4 \%)$. Based on these results, we speculate that Acinetobacter spp. (PRS4) utilized the aquaculture sewage phosphorus. Heterotrophic bacteria such as PRS4 are thought to be able to store polyphosphate in their cells under aerobic or anoxic conditions, which would enable the simultaneous assimilation of phosphorus during energy uptake from external carbon sources (Burut-Archanai et al. 2013, Liu et al. 2019). This assumption was verified by the existing literature, confirming the phosphorus removal potential of Acinetobacter spp. The same mechanisms mentioned above could explain the TP removal enhancement by biochar-immobilized PRS4. In addition, the phosphorus accumulation capacity of PRS4 was much higher $(25 \%)$ than that of the EMs in this study, which also indicates that PRS4 is more suitable than EMs for TP removal.

\subsection{Assessment of water quality and bio-safety with utilization of biochar-immobilized isolated bacteria for practical crab aquaculture}

Aquaculture water quality is one of the main factors influencing the environmental ecology and health of aquatic animals. In our study, dynamic variations in DIN $\left(\mathrm{NH}_{4}{ }^{+}-\mathrm{N}, \mathrm{NO}_{2}{ }^{-} \mathrm{N}\right.$ and $\left.\mathrm{NO}_{3}{ }^{-}-\mathrm{N}\right)$ and TP levels were monitored during $90 \mathrm{~d}$ of Eriocheir sinensis cultivation. The results can guide optimization of the applied BIAP dosage, thus reducing operating expenses for water purification. A total of 3 treatments with BIAP dosages of $2 \mathrm{~g} \mathrm{l}^{-1}$ (T7), $4 \mathrm{~g} \mathrm{l}^{-1}$ (T8) and $6 \mathrm{~g} \mathrm{l}^{-1}$ (T9) were conducted; the results are illustrated in Fig. 5.

Clearly, in the control group (T6) without the addition of BIAP, the DIN and TP contents increased from $0.8-10.1$ and $0.2-2.6 \mathrm{mg} \mathrm{l}^{-1}$, respectively, with the continuous addition of fish bait. With the addition of BIAP, these concentrations were maintained within a certain range with only small fluctuations. It should be noted that with the application of BIAP at a level of $4 \mathrm{~g} \mathrm{l}^{-1}$, the level of nutrients fluctuated below the clean water threshold for aquaculture (DIN: $\leq 1 \mathrm{mg} \mathrm{l}^{-1}$; TP: $\leq 0.2 \mathrm{mg} \mathrm{l}^{-1}$ ) as defined in the environmental quality standard for surface water (GB 3838-2002). By further increasing the dose (6 g $\mathrm{l}^{-1}$ ) of BIAP, more substantial water purification effects were obtained, with DIN and TP levels fluctuating around approximately 0.45 and $0.09 \mathrm{mg} \mathrm{l}^{-1}$, respectively. These results suggest that, in practical applications, immobilized ANRS5 and PRS4 are capable of transforming different forms of nitrogen and phosphorus into their respective components in several biochemical steps (Cai et al. 2007, Guedes et al. 2019, Qin et al. 2019). These immobilized strains likely experience rapid adaptation and growth in aquatic environments, and play an important role in nitrogen and phosphorus cycles. Furthermore, at $4 \mathrm{~g} \mathrm{l}^{-1} \mathrm{BIAP}$, the cost of this application (including raw materials, production and labor) was calculated to be approximately US\$10 per $1000 \mathrm{~m}^{2}$, which is quite acceptable.

The bio-safety of the isolated strains to aquatic animals in farming environments has not received great attention. In our study, this issue was related to the survival rate, weight, stocking density, biomass, crude protein, crude fat and water content of E. sinensis with BIAP application $\left(\begin{array}{lll}4 & \mathrm{~g} \mathrm{l}^{-1}\end{array}\right)$; the results are shown in Fig. 6 and Table 5. There was no significant difference in survival rate between the control and experimental treatments during crab cultivation. In addition, the cumulative survival rate of E. sinensis in the experimental group (88\%) was slightly higher than that in the control group $(86 \%)$ at harvest. With respect to yield and quality, crab weight, stocking density, biomass, crude protein, crude fat and water content in the experimental group were $231 \mathrm{~g}$ ind. ${ }^{-1}, 12.3 \mathrm{~kg} \mathrm{~m}{ }^{-2}, 0.62 \mathrm{~g} \mathrm{~cm}^{-3}$, $18.1 \%, 62.3 \%$ and $10.8 \%$, respectively, which were improvements compared to those in the control group. Considering the very large cell quantity (approximately $21.6 \times 10^{8} \mathrm{cfu}^{-1}$ ) that was added to the aquatic environment, the results indicate that BIAP presents no bio-safety concerns for E. sinensis and might represent a potential economic value for aquaculture operations.

\section{CONCLUSIONS}

The biochar prepared from maize straw possessed a large SSA and complex pore structure, which was beneficial for immobilization of the isolated bacteria. The satisfactory surface physico-chemical properties of the prepared biochar also enhanced the 
$\mathbf{a}$
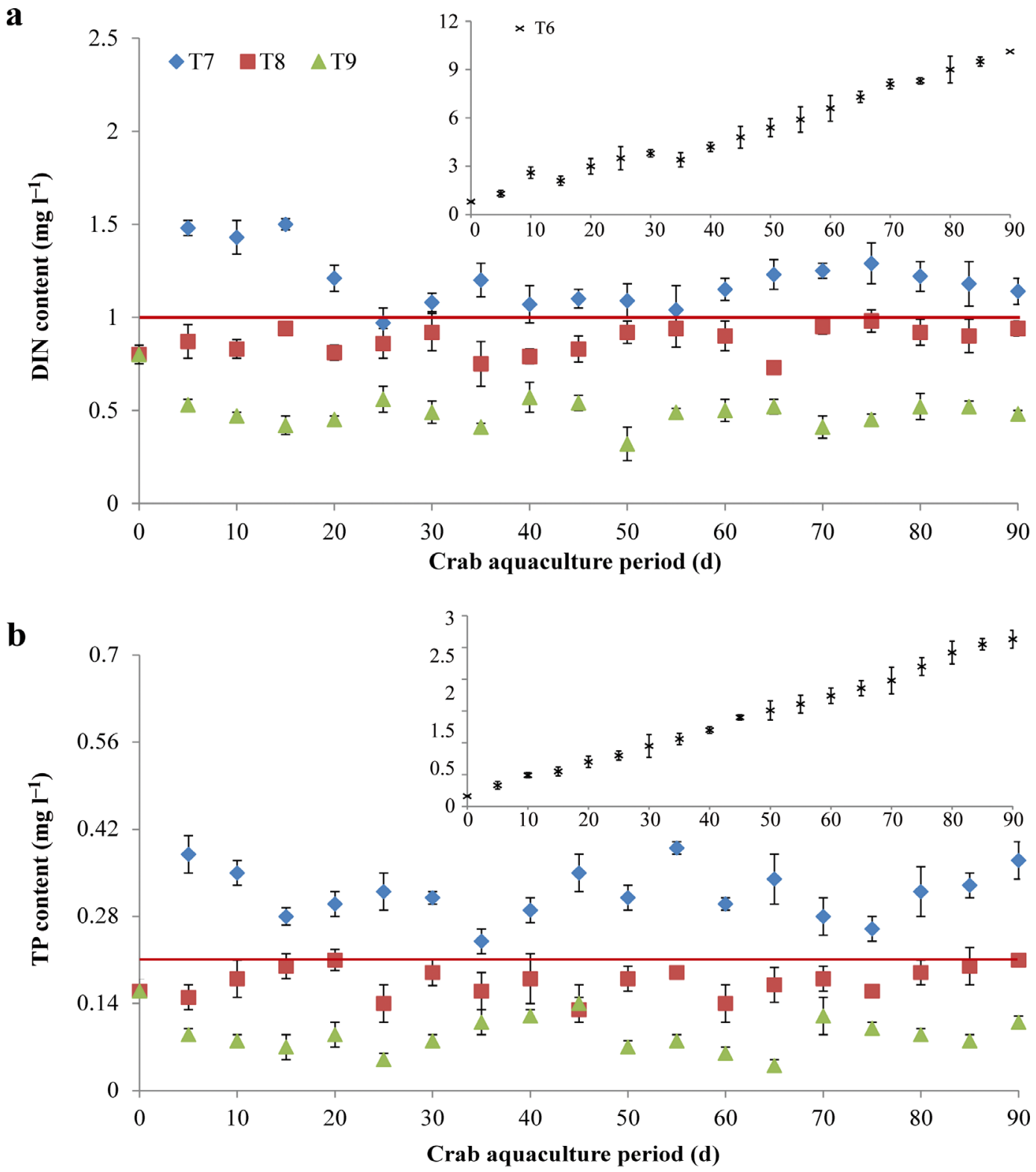

Fig. 5. Dynamic variations of dissolved inorganic nitrogen (DIN) and total phosphorus (TP) contents during crab aquaculture with applications of $0 \mathrm{~g} \mathrm{l}^{-1}$ (T6) (insets), $2 \mathrm{~g} \mathrm{l}^{-1}$ (T7), $4 \mathrm{~g} \mathrm{l}^{-1}$ (T8) and $6 \mathrm{~g} \mathrm{l}^{-1}$ (T9) of biochar-immobilized ammonia nitrogen and phosphate removal strains, respectively. Red line: clean criterion of dissolved inorganic nitrogen and TP contents for aquaculture according to the Chinese Environmental Quality Standard for Surface Water (GB3838-2002). Error bars: SD

adsorption of pollutants in the aquaculture sewage. The isolated Sphingomonas sp. PDD-57b-25 and Acinetobacter towneri were more efficient in assimilating DIN and polyphosphate compared to currently used bacterial agents. With the application of a specific amount of BIAP, the water quality in a recirculating Eriocheir sinensis aquaculture system was maintained in a healthy range according to the relevant water quality standard. In addition, BIAP presented no bio-safety risks for $E$. sinensis, which demon- strates its potential economic value in sewage remediation and aquaculture applications.

In summary, the results in the present study are important in the context of the existing literature and for the practical application of biochar-immobilized bacteria as a decontamination technology for agricultural sewage. Moreover, we believe that the experimental and evaluation methodology developed here may be applied as a useful tool for practical intensive aquaculture in other RASs. 


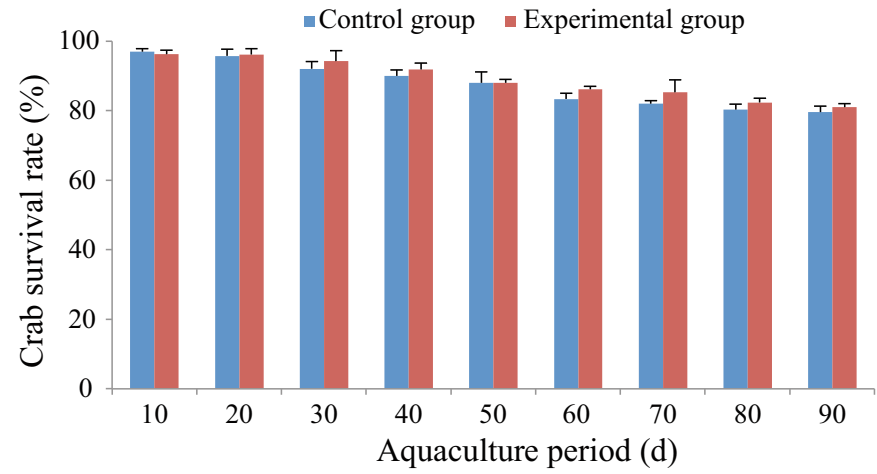

Fig. 6. Survival of crabs with practical application of biocharimmobilized ammonia nitrogen and phosphate removal strains (ANRS and PRS) at $4 \mathrm{~g} \mathrm{l}^{-1}$. Control group did not receive biochar-immobilized ANRS and PRS; experimental group: challenged by biochar-immobilized ANRS and PRS.

Error bars: SD; crabs sampled per treatment: 50

Table 5. Mean $( \pm \mathrm{SD})$ yield and quality of Eriocheir sinensis crabs with practical application of biochar-immobilized ammonia nitrogen and phosphate removal strains (ANRS and PRS; $4 \mathrm{~g} \mathrm{l}^{-1}$ ). Control group was given no biochar-immobilized ANRS and PRS; experimental group was challenged by biochar-immobilized ANRS and PRS. Crabs sampled per treatment $=50$; all measured crab parameters were significantly different between treatments at $\mathrm{p}<0.01$

\begin{tabular}{|lccc|}
\hline Indexes & Unit & $\begin{array}{c}\text { Control } \\
\text { group }\end{array}$ & $\begin{array}{c}\text { Experimental } \\
\text { group }\end{array}$ \\
\hline Weight & $\mathrm{g} \mathrm{ind.}^{-1}$ & $182 \pm 4.5$ & $231 \pm 6.3$ \\
Stocking intensity & $\mathrm{kg} \mathrm{m}^{-2}$ & $9.7 \pm 0.8$ & $12.3 \pm 1.4$ \\
Biomass & $\mathrm{g} \mathrm{cm}^{-3}$ & $0.48 \pm 0.05$ & $0.62 \pm 0.07$ \\
Crude protein & $\%$ & $16.3 \pm 0.3$ & $18.1 \pm 0.4$ \\
Crude fat & $\%$ & $58.6 \pm 2.7$ & $62.3 \pm 2.3$ \\
Water content & $\%$ & $9.4 \pm 0.7$ & $10.8 \pm 0.9$ \\
\hline
\end{tabular}

Acknowledgements. This work was financially supported by the Jiangsu Scientific Research Program (BE2015705 and BE2017765), the Fundamental Research Funds for the Central Universities (2019B45214 and 2019B18314) and the Science and Technology Project of the Nanjing Water Conservancy Bureau (20130317-1).

\section{LITERATURE CITED}

Acevedo B, Camion AC, Corona JE, Borras L, Barat R (2015) The metabolic versatility of PAOs as an opportunity to obtain a highly P-enriched stream for further P-recovery. Chem Eng J 270:459-467

Agyarko-Mintah E, Cowie A, Van Zwieten L, Pal Singh B, Smillie R, Harden W, Fornasier F (2017) Biochar lowers ammonia emission and improves nitrogen retention in poultry litter composting. Waste Manage 61:129-137

Burut-Archanai S, Eaton-Rye JJ, Incharoensakdi A, Powtongsook S (2013) Phosphorus removal in a closed recirculating aquaculture system using the cyanobacterium Synechocystis sp. PCC 6803 strain lacking the SphU regulator of the Pho regulon. Biochem Eng J 74: 69-75
Cai TM, Guan LB, Chen LW, Cai S, Li XD, Cui ZL, Li SP (2007) Enhanced biological phosphorus removal with Pseudomonas putida GM6 from activated sludge. Pedosphere 17:624-629

Chen WM, Li YS, Sheu SY (2016) Sphingomonas piscinae sp. nov. isolated from a fish pond. Int J Syst Evol Microbiol 66:5301-5308

* Dalgaard T, Hutchings N, Dragosits U, Olesen JE, Kjeldsen C, Drouet JL, Cellier P (2011) Effects of farm heterogeneity and methods for upscaling on modelled nitrogen losses in agricultural landscapes. Environ Pollut 159:3183-3192

* de-Bashan LE, Antoun H, Bashan Y (2008) Involvement of indole-3-acetic acid produced by the growth-promoting bacterium Azospirillum spp. in promoting growth of Chlorella vulgaris. J Phycol 44:938-947

Fergola P, Cerasuolo M, Pollio A, Pinto G, Dellagreca M (2007) Allelopathy and competition between Chlorella vulgaris and Pseudokirchneriella subcapitata: experiments and mathematical model. Ecol Modell 208:205-214

Filipe CDM, Daigger GT, Grady CPL (2001) Effects of pH on the rates of aerobic metabolism of phosphate-accumulating and glycogen-accumulating organisms. Water Environ Res 73:213-222

Fitzgerald CM, Camejo P, Oshlag JZ, Noguera DR (2015) Ammonia-oxidizing microbial communities in reactors with efficient nitrification at low-dissolved oxygen. Water Res 70:38-51

* Fu Q, Yan JW, Li H, Li TX, Hou RJ, Liu D, Ji Y (2019) Effects of biochar amendment on nitrogen mineralization in black soil with different moisture contents under freezethaw cycles. Geoderma 353:459-467

* Gelfand I, Barak Y, Chen EZ, Cytryn E, Krom M, Neori A, Rijn VJ (2003) A novel zero-discharge intensive seawater recirculating system for culture of marine fish. J World Aquacult Soc 34:344-358

*Guedes IA, Pacheco ABF, Vilar MCP, Mello MM, Marinho MM, Lurling M, Azevedo SMFO (2019) Intraspecific variability in response to phosphorus depleted conditions in the cyanobacteria Microcystis aeruginosa and Raphidiopsis raciborskii. Harmful Algae 86:96-105

Kirimura K, Nakagawa H, Tsuji K, Matsuda K, Kurane R, Usami S (1999) Selective and continuous degradation of carbazole contained in petroleum oil by resting cells of Sphingomonas sp. CDH-7. Biosci Biotechnol Biochem 63: 1563-1568

Li J, Hu Z, Li FZ, Fan JL, Zhang J, Li FM, Hu HY (2019) Effect of oxygen supply strategy on nitrogen removal of biochar-based vertical subsurface flow constructed wetland: intermittent aeration and tidal flow. Chemosphere 223:366-374

Li SS, Peng CR, Cheng TS, Wang C, Guo LL, Li DH (2019) Nitrogen-cycling microbial community functional potential and enzyme activities in cultured biofilms with response to inorganic nitrogen availability. J Environ Sci (China) 76:89-99

KLiang YH, Li D, Zhang XJ, Zeng HP, Yang Z, Cui SM, Zhang J (2014) Nitrogen removal and microbial characteristics in CANON biofilters fed with different ammonia levels. Bioresour Technol 171:168-174

Liu YL, Li X, Kang XR, Yuan YX (2014) Performance of denitrifying phosphorus removal of Acinetobacteria strain at low temperature. Int Biodeterior Biodegradation 95: 135-138

* Liu H, Yang YK, Ge YH, Zhao L, Long S, Zhang RC (2016) Interaction between common antibiotics and a Shewanella 
strain isolated from an enhanced biological phosphorus removal activated sludge system. Bioresour Technol 222: $114-122$

Liu RB, Hao XD, Chen Q, Li J (2019) Research advances of Tetrasphaera in enhanced biological phosphorus removal: a review. Water Res 166:115003

Peng PC, Huang H, Ren HQ, Ma HJ and others (2018) Exogenous $\mathrm{N}$-acyl homoserine lactones facilitate microbial adhesion of high ammonia nitrogen wastewater on biocarrier surfaces. Sci Total Environ 624: 1013-1022

Qin FJ, Shen T, Yang HX, Qian JC and others (2019) Dietary nano cerium oxide promotes growth, relieves ammonia nitrogen stress, and improves immunity in crab (Eriocheir sinensis). Fish Shellfish Immunol 92:367-376

Rezaei Rashti M, Esfandbod M, Phillips IR, Chen CR (2019) Aged biochar alters nitrogen pathways in bauxite-processing residue sand: environmental impact and biogeochemical mechanisms. Environ Pollut 247:438-446

Su CY, Zhao LJ, Liao LM, Qin JJ and others (2019) Application of biochar in a CIC reactor to relieve ammonia nitrogen stress and promote microbial community during food waste treatment. J Clean Prod 209:353-362

Sun L, Zhao XX, Zhang HF, Zhang YQ (2015) Biological characteristics of a denitrifying phosphorus-accumulating bacterium. Ecol Eng 81:82-88

Wang JL, Wang SZ (2019) Preparation, modification and environmental application of biochar: a review. J Clean Prod 227:1002-1022

Wu Y, Luo JY, Zhang Q, Muhammad A, Fang F, Xue ZX, Cao JS (2019) Potentials and challenges of phosphorus

Editorial responsibility: Catriona MacLeod,

Hobart, Tasmania, Australia recovery as vivianite from wastewater: a review. Chemosphere 226:246-258

* Yabuuchi E, Yano I, Oyaizu H, Hashimoto Y (1990) Proposals of Sphingomonas paucimobilis gen. nov. and comb. nov., Sphingomonas parapaucimobilis sp. nov., Sphingomonas yanoikuyae sp. nov., Sphingomonas adhaesiva sp. nov., Sphingomonas capsulata comb, nov., and two genospecies of the genus Sphingomonas. Microbiol Immunol 34:99-119

* Yu JY, Yu JY, Chen XM, Zhou X, Cai YX, Cai HY, Yan PS (2019) Effects of fermented protein feed on the growth performance of pond-raised crab. Aquacult Fish 4:149-155

* Yu NL, Zhao CK, Ma BR, Lia SS and others (2019) Impact of ampicillin on the nitrogen removal, microbial community and enzymatic activity of activated sludge. Bioresour Technol 272:337-345

* Yun L, Yu ZH, Li YY, Luo P, Jiang X, Tian YS (2019) Ammonia nitrogen and nitrite removal by a heterotrophic Sphingomonas sp. strain LPN080 and its potential application in aquaculture. Aquaculture 500:477-484

* Zhou WZ, Huang ZS, Sun CP, Zhao HX, Zhang YZ (2016) Enhanced phosphorus removal from wastewater by growing deep-sea bacterium combined with basic oxygen furnace slag. Bioresour Technol 214:534-540

* Zhu YX, Tu XJ, Chai X, Wei Q, Guo L (2018) Biological activities and nitrogen and phosphorus removal during the Anabaena flos-aquae biofilm growth using different nutrient form. Bioresour Technol 251:7-12

K Zhu YY, Shan BQ, Huang JY, Teasdale PR, Tang WZ (2019) In situ biochar capping is feasible to control ammonia nitrogen release from sediments evaluated by DGT. Chem Eng J 374:811-821

Submitted: November 30, 2019; Accepted: May 14, 2020 Proofs received from author(s): June 25, 2020 